\title{
German research agency stifles creativity
}

Munich

Researchers such as Mark Benecke should be the future of German science. With most of his contemporaries still only just finishing their PhDs, this 29-year-old entomologist at the University of Cologne is already applying for research grants under his own steam. Yet earlier this year, his application to the Deutsche Forschungsgemeinschaft (DFG), the country's main grant-giving agency for university research, was turned down after an eight-month wait. "The DFG had huge difficulties in assigning my proposal to appropriate referees," he says.

Benecke's field is forensic entomology, which can, for example, reveal how long a corpse has lain undiscovered by studying the insects on it. And it is typical of the novel research areas that, according to many scientists, the DFG seems unable to assess. They charge that the agency's aversion to taking risks, lengthy review procedures - in some cases more than twelve months - and inability to deal with interdisciplinary proposals threaten career opportunities for young researchers.

Ultimately, some researchers warn, the agency's outmoded procedures could weaken Germany's position in cutting-edge areas of science. And feelings are running so high that the debate has spilled over into the science and correspondence pages of leading German newspapers. Germany risks the "migration of the best minds of its next generation of scientists", says Ralf Müller, a German electrical engineer at the University of Princeton in New Jersey.

Many question the DFG's ability to handle interdisciplinary research applications. Its elected external referees are organized into narrow, discipline-orientated boards, and critics claim they fail to keep pace with fast-moving areas such as biomedicine, ecology, informatics or materials research. Time is lost because the DFG has trouble finding referees for innovative or cross-disciplinary applications, they say.

"The key problem is that funding decisions are made by a small group of overworked honorary referees, nominated by the traditional German scientific societies," says Michael Cross, a young British molecular biologist at the University of Leipzig.

The DFG's review system "is not as flexible as it should be", agrees Gerhard Neuweiler, a professor of zoology at the University of Munich and former president of Germany's science council, the Wissenschaftsrat. "Unfortunately, this tends particularly to disadvantage innovative researchers in the most competitive areas."

Peter Uetz, for example, applied unsuccesfully to the DFG in 1997 for a project in functional genomics. Uetz then turned to the

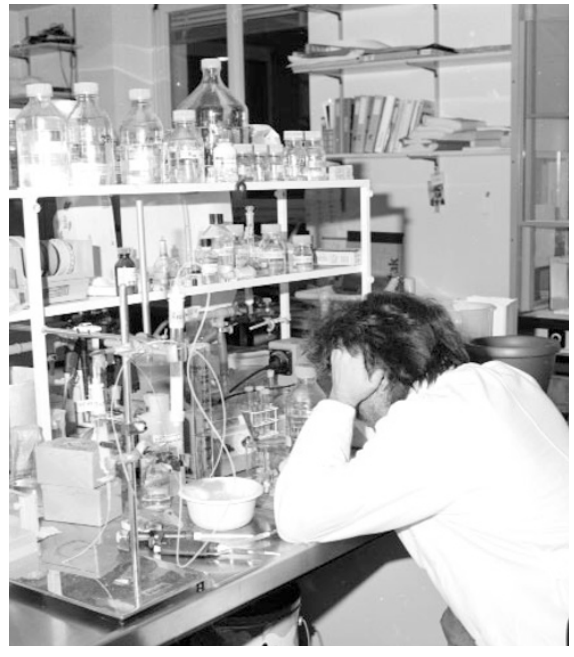

Benchmark of despair: innovative German researchers find it hard to get grants.

German Academic Exchange Service, and eventually received a grant allowing him to do research at the University of Washington in Seattle. His first results were published last month in Nature $(403,623 ; 2000)$.

"Ironically, the DFG turned down my proposal at a time when its president, ErnstLudwig Winnacker, was strongly emphasizing the strategic importance of functional genomics in Germany," says Uetz.

Many German scientists look enviously across the Atlantic, where they feel funding agencies are prepared to support risky projects, trusting that one of them will turn out to be a big breakthrough. They criticize the DFG's tendency to cover itself against possible failures at the expense of missing out on the new and unexpected. Faced with such conservatism, young researchers such as Müller and Uetz are voting with their feet.

DFG officials defend their record, pointing out that decisions on grant applications take on average between five and six months
- comparable to organizations such as the US National Science Foundation and the British Medical Research Council. But critics say this respectable figure includes grants in the humanities and traditional scientific disciplines, where the DFG's performance is not under attack.

The DFG had promised organizational changes after similar criticisms were levied by an external evaluation last year (see Nature 399, 395; 1999). But many scientists are disappointed with the lack of progress, and some suggest that a more pluralistic system may be the answer. "Flexibility would increase very quickly if the DFG lost its monopoly," says Oliver Kempski, a professor of medicine at the University of Mainz.

Unlike its counterparts in the United States and Britain - and private foundations such as the German Volkswagen Foundation - the DFG has no established mechanisms to 'fast-track' applications in hot research areas such as computer-based functional genomics or molecular medicine. "In highly competitive areas, one week can be a very decisive factor," says Neuweiler.

Cross suggests that the DFG should allow interdisciplinary projects to be reviewed simultaneously by referee boards representing different disciplines. In particularly complicated or urgent cases, he adds, applicants should be given the chance to attend referees' meetings to explain their ideas face to face.

Eva-Maria Streier, the DFG's spokeswoman, says the agency is open-minded about this idea. She points out that the agency is already experimenting with such parallel reviewing, although merely in addition to its normal procedures.

Unless the DFG makes urgent reforms, say some researchers, Germany risks losing international competitiveness. "Eventually you will find yourself in the second division," says Cross. Quirin Schiermeier and Patrick Weydt

\section{EU centres saved from 'catastrophe'}

\section{London}

European research ministers intend to reverse controversial rules which have prevented the European Union's Fifth Framework Programme of Research (FP5) from supporting the running costs of European research facilities.

Life-science research facilities were thrown into crisis last year when officials at the European Commission unexpectedly said that institutions such as the European Bioinformatics Institute (EBI) in Cambridge and the European Mouse Mutant Archive (EMMA) at Monterotondo near Rome could not be funded as service facilities.
Both facilities, which life scientists hold to be essential for the development of their disciplines, had been set up with FP4 support, with the understanding that funding would be continued in future framework programmes (Nature 402, 3; 1999).

The Council of Ministers had authorized support for infrastructures for a wide range of activities in FP5. However, commission officials interpreted the text of the FP5 document as excluding running costs for research facility infrastructures.

But José Mariano Gago, the Portugese science minister, told an informal meeting 
in Lisbon last week, where European Union (EU) research ministers met with heads of European science organizations and a handful of Nobel laureates, that he is not sure the interpretation was legal.

The ministers will now ask the commission to reverse its decision not to distribute money to the service facilities, said Gago. If the commission disagrees, he said, then the ministers will take a decision at their next formal meeting in June to unambiguously change the rules.

"Clearly the decision was not what the council of ministers intended," Gago told Nature. "All the ministers think the situation is quite unfair and should be resolved immediately. The ministers did not decide [to stop funding for EBI and EMMA] ... it was a decision by the commission which was taken in a bureaucratic way during the summer holidays."

Gago says the ministers believe infrastructure support to be "essential" for research and development in Europe.

Glauco Tocchini-Valentini, secretary general of the European Molecular Biology Conference, welcomes Gago's statement. "Facilities like EBI and EMMA are close to catastrophe, so intervention at the political level is urgently needed."

But the commission remains reluctant to "create a precedent for direct financing of infrastructures", says a spokeswoman. The FP5 budget is limited, and demand, particularly in the life sciences, is growing, she says. The commission is setting up a working group to look into other options for saving EMMA and EBI.

The Lisbon meeting was the first time that EU research ministers had met with such a wide range of representatives from the scientific community. The EU no longer has a formal European scientific advisory structure. The advisory European Science and Technology Assembly, which was associated with FP4, was dissolved two years ago by former research commissioner Edith Cresson (see Nature $394,817 ; 1998)$ and has not been replaced.

Nobel laureates at the meeting heavily criticized EU peer review systems and called for transparency and efficiency. Gago told Nature he thought a formal mechanism was needed for closer cooperation between the scientific community, the council and the commission. "The European research organizations and the national research councils must be part of the normal consultation process of the council and the commission," says Gago. Natasha Loder

\section{New form of hydrogen power provokes scepticism}

Washington

A company claiming to have made a revolutionary breakthrough in chemistry and energy production by creating a novel form of hydrogen has threatened several prominent physicists with possible legal action unless they stop disparaging the science behind the claim.

A law firm representing the energy company BlackLight Power, Inc. of Cranbury, New Jersey, sent letters earlier this month to Nobel laureate Philip Anderson of Princeton University, Michio Kaku of the City University of New York, Paul Grant of the non-profit energy agency EPRI and Robert Park of the American Physical Society, requesting that they stop making defamatory comments in the press about the company and its president, Randell Mills.

BlackLight has already attracted more than $\$ 20$ million in private investment to back its proprietary chemical process. According to Mills, this process has generated energy far in excess of that put into the system. Underlying the process is Mills's theory that hydrogen atoms can be made to exist below their ground state in a form he calls "hydrinos".

The four scientists cited by BlackLight have been quoted in the The Village Voice, Dow Jones Newswire and other publications as dismissing the claim because it violates established principles of physics. Kaku, commenting on the company's investors, which include several large utility companies, was quoted by the Dow Jones Newswire as saying "There's a sucker born every minute".

The negative publicity comes at a bad time for BlackLight, as the company is considering a public stock offering this year. Mills accuses his critics of "trying to destroy our business", and bristles at the charge that he has produced no data to back his claims.

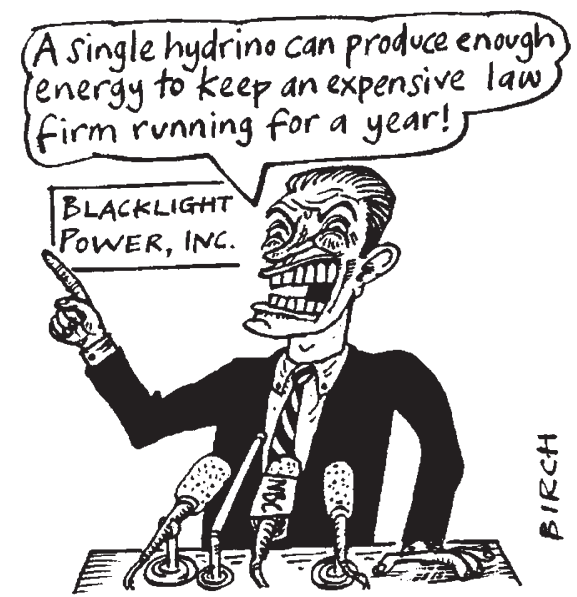

He points to a conference presentation he gave last year at a regional meeting of the American Chemical Society, and says he intends to present at the society's national meeting this month.

He also says he is preparing papers for submission to major scientific journals, and that others have replicated his results and are also submitting to journals.

So far, though, Blacklight's results have been published only on the company's website (www.blacklightpower.com) or in journals that many mainstream scientists say lack rigor and are dominated by other researchers investigating unconventional some say impractical — forms of energy.

Nor has the company's recent award of a US patent for "Lower-energy hydrogen methods and structures" impressed the critics. Grant, an expert in high-temperature superconductors, was quoted by Dow Jones as saying, "A patent means nothing. It carries no weight as scientific validation." The patent examiners based their decision on presentations by BlackLight, according to Mills.

Park says, "the issue is not whether their stuff is out there for review. The issue is whether anybody believes it, and whether people who don't believe it have a right to say they don't believe it." He continues to discount BlackLight's claims as "pure boloney", and will say so in his book, Voodoo Science, due to be published by Oxford University Press this spring. "There'll be no changes," he says.

Despite the implied threat in his letter, BlackLight's attorney Michael O’Hayre says that "we're not interested in stifling any free and open debate. Right now we're just investigating what to do."

Park says he has turned the letter over to the solicitor at the American Physical Society, and is confident that, should BlackLight decide to sue, the courts would side with the physicists. The scientific community would also be likely to rally round the defendants, he says, just as they did a decade ago when lawyers for proponents of cold fusion sent out threatening letters.

Although legal threats in scientific disputes are surprisingly rare, Park says scientists can be "pretty easy to intimidate". With legal fees to defend against a libel charge sometimes running to tens of thousands of dollars, he admits some scientists could decide that it's not worth the risk speaking to the press about controversial research. And that, he says, would "leave the public vulnerable”. 